\title{
Radiographic Examination of Talocrural Joint Morphometry in Individuals with Normal Joint Anatomy
}

\author{
Articulatio Talocruralis Morfometrisinin Anatomik Olarak Normal Eklem Yapısına Sahip Bireylerin \\ Radyografilerinde Değerlendirilmesi
}

\author{
Muhammet Bora Uzuner' ${ }^{1}$, Mustafa F. Sargon², Ferhat Geneci ${ }^{3}$, Mert Ocak², Tanzer Sancak', \\ Deniz Demiryürek², Burak Bilecenoğlu ${ }^{5}$
}

${ }^{1}$ Department of Anatomy, Kafkas University Faculty of Medicine, Kars; ${ }^{2}$ Department of Anatomy, Hacettepe University Faculty of Medicine; ${ }^{3}$ Department of Anatomy, Yildirim Beyazut University Faculty of Medicine; ${ }^{4}$ Department of Radiology, TOBB ETÜ Faculty of Medicine; 'Department of Anatomy, Ankara University Faculty of Dentistry, Ankara, Turkey

\begin{abstract}
Aim: The traumas of the talocrural joint are very common in population. Therefore; the anatomy and morphometry of this joint has a great importance. The aim of this study was to examine the morphometry of talocrural joint in large series of patients according to age and sex in order to add some new knowledge to the literature. At the same time, according to the results of the research, it is aimed to give a way for field-specific prosthesis production to the prosthetic producers.
\end{abstract}

Material and Method: In this study; the talocrural joint radiographs of 274 anatomically normal patients (134 males, 140 females) were examined. The morphometric measurements of the defined parameters were done and their statistical analysis were performed according to age and sex. As far as we know, from our parameters; the mediolateral diameter of tibia (TML), the mediolateral diameter of fibula (FML), surface area of trochlea tali (TTA) and SIGMA angles were firstly defined in this study. Additionally; the innermost distance of talocrural joint (ATI), the outermost distance of talocrural joint (ATD), the angles in between the medial malleolus and talus (DELTA), the lateral malleolus and talus (ALFA) and the sagittal length of trochlea tali (TSU) were also measured.

Results: In the comparison of TML, FML, TTA, ATI, ATD measurement sand ALFA angle in both sexes; they were found to be higher in males than in females. However; TSU and SIFGMA angle were found to be higher in females, when compared with males. The DELTA angle was nearly the same in both sexes.

Conclusion: These morphometric analyses were performed in a huge number of anatomically normal patients' radiographs and therefore; we believe that the study will add a new knowledge to the literature, will help to the clinicians who are interested in the ankle joint and will be useful for the companies who are working on implant technology.

Key words: talocrural joint; ankle joint; anatomy; morphometry; radiography

Muhammet Bora Uzuner, Kafkas Üniversitesi Tip Fakültesi, Anatomi Anabilim Dal, Kars, Türkive, Tel.05058269606 Email.borauzuner1@hotmail.com Geliş Taribi: 28.11.2018 • Kabul Taribi: 11.12.2018
ÖZET

Amaç: Articulatio talocruralis travmalarına toplumda çok sık rastlanması nedeniyle bu eklemin anatomik yapısı ve morfometrisinin çok iyi bilinmesi gereklidir. Bu çalıșmada articulatio talocruralis morfometrisini yaș grupları ve cinsiyet parametrelerine göre geniș serilerde değerlendirerek literatüre katkı sağlamak ve araștırma sonuçlarına göre protez üreticilerine daha spesifik protez üretimi yapılabilmesi için yol göstermek amaçlanmıștır.

Materyal ve Metot: Çalș̦mada, ayak bileği ekleminde herhangi bir patolojisi bulunmayan ve eklemin anatomik olarak normal olduğunun tespit edildiği 274 bireye ait (134 erkek, 140 kadın) ayak bileği radyografileri incelendi. Tanımlanan parametrelerin morfometrik ölçümleri yapılarak elde edilen sonuçlar yașa ve cinsiyete bağlı olarak istatistiksel olarak karșılaștırıldı. Bildiğimiz kadarıla morfometrik ölçümlerini yaptığımız parametreler arasında yer alan tibia'nın mediolateral çapı (TML), fibula'nın mediolateral çapı (FML), trochlea tali'nin yüzey alanı (TTA) ve SIGMA açısı literatürde ilk defa bizim tarafımızdan tarif edilmiștir. Ayrıca; çalıșmada articulatio talocruralis'in en iç noktaları arasındaki mesafe (ATi), articulatio talocruralis'in en dıș noktaları arasındaki mesafe (ATD), malleolus medialis ile talus arasındaki açı (DELTA) malleolus lateralis ile talus arasındaki açı (ALFA) ve trochlea tali'nin sagittal uzunluğu (TSU) ölçüldü.

Bulgular: Çalıșmada, cinsiyetler arasında TML, FML, TTA, ATI, ATD uzunlukları ve ALFA açısı değerlendirildiğinde; erkeklere ait ölçüm sonuçları kadınlardan daha fazla olduğu tespit edildi. Bununla birlikte; kadınlarda TSU ve SIGMA açısının erkeklerden daha yüksek olduğu bulundu. Kadınlarda ve erkeklerde ölçülen DELTA açıları karșılaștırıldığında her iki cinste yaklașık olarak eșit değerler saptandı.

Sonuç: Geniș serilerde ve normal bireylere ait articulatio talocruralis radyografilerinde gerçekleștirilen bu morfometrik analizlerin literatüre katkı sağlayacağını, ayak bileği ile ilgilenen hekimlere yol göstereceğini ve implant üreten firmalara önemli bir katkı sağlayacağını düșünmekteyiz.

Anahtar kelimeler: articulatio talocruralis; ayak bileği; anatomi; morfometri; radyografi 


\section{Introduction}

The talocrural joint is one of the joints in the body that is most frequently exposed to trauma ${ }^{1}$. This joint ensures the unity of the leg area with the foot area and has a great functional importance. Body weight is transmitted to the talus through means of tibia and fibula. The talus then transmits the weight to navicular bone and calcaneus ${ }^{2,3}$. Talocrural joint is a trochlear type joint located between the talus, tibia and fibula. The flexion and extension movements of the foot ankle occur in this joint. Out of all injuries caused by sports, $20 \%$ consist in injuries of the talocrural joint, 33\%-73\% consist in lateral foot ankle twistings and another $20 \%$ consists in foot ankle injuries $^{4}$. Injuries of the talocrural joint are generally classical inversion traumas which may occur frequently.

The morphometric structure of the talocrural joint plays a pivotal role because of the fact that this joint is relatively more exposed to traumas than other joints, especially to foot ankle twistings. Furthermore, a good knowledge on the morphometry of the talocrural joint can serve as a helpful guide to doctors who are interested in this area and can also pave the way to the development of new methods in cure planning.

\section{Material and Method}

This study was conducted in the Department of Anatomy at the Facultyof Medicine at Hacettepe University in Ankara. Direct radiographies were selected from among the patients who have been registered at the Radiology Department of the TOBB Economy and Technology University (ETU) Hospital from 2006 through 2016.

Presence of pathologies served as the excluding criterion in the selection of radiographies. Individuals with injuries or ruptures in ligaments; fractures in bones that affect the joint; or individuals suffering from luxacion or subluxacion and also radiographies that included radiologic artefacts or those where the borders of the joint were not clear due to the low quality of the image were not included in the study.

A total of 274 radiographies were used in this study, out of which 134 male and 140 female radiographies that met the criteria. The radiographies of the individuals have been divided into a total of seven decades, which were formed based on the individuals' age that ranged from 10 to 85 and converted to DICOM format. The selected images in the radiography device were those pertaining to individuals whose manual basic anteroposterior and lateral positions were in accordance with the standard protocol set forth by the World Health Organization. In this study we used the Film Workstation (v. 3.4) software and CTAn (ver. 1.12.9, Skyscan) software compatible with the PACS system of the TOBB ETÜ Hospital.

\section{The parameters that were measured in the study}

Measurement of the Sagittal Length of the Trochlea Tali (TSU): After having identified the front and backmost ends of the trochlea tali in the lateral radiographies of the ankle, the sagittal length of the trochlea tali has been measured (Fig. 1a).

Measurement of the Angle between the Edges of the Calcaneus and the Edges of the Talus (SIGMA angle): We measured the lower angle (SIGMA angle) formed between the plane created from the most protruding back point on the lower face of the calcaneus to the most protruding medial front point of the trochlea tali on the one hand, and the plane created from the most protruding front point on the lower face of the calcaneus to the most protruding medial back point of the trochlea tali on the other (Fig. 1b).

Measurement of the Surface Area of the Trochlea Tali (TTA): After identifying the trochlea tali, we selected the ROIs (region of interest) and set the histogram half automatically by defining the trochlea talis bone area existing between the boundaries. The bone surface area was calculated via the CTAn software in two dimensions (Fig. 1 c).

The Measurement of the Mediolateral Diameter of the Tibia (TML): In the transverse plane, from the anterior edge of the tibial joint surface passing through the ceiling of articulatio talocruralis; The mediolateral distance was measured between the most prominent points of the tibia. (Fig. $1 \mathrm{~d}$ ).

Measurement of the Mediolateral Diameter of the Fibula (FML): In the transverse plane, from the anterior edge of the tibial joint surface passing through the ceiling of articulatio talocruralis; The mediolateral distance was measured between the most prominent points of the fibula. (Fig. 2a).

Measurement of the distance between the innermost points of the talocrural joint at the medial and lateral malleoli (ATI): We measured the distance between the innermost points of the talocrural joint by firstly defining the most medial points of the medial and lateral malleoli and in a way that it passed over the upper border of the talar dome (Fig. 2b). 

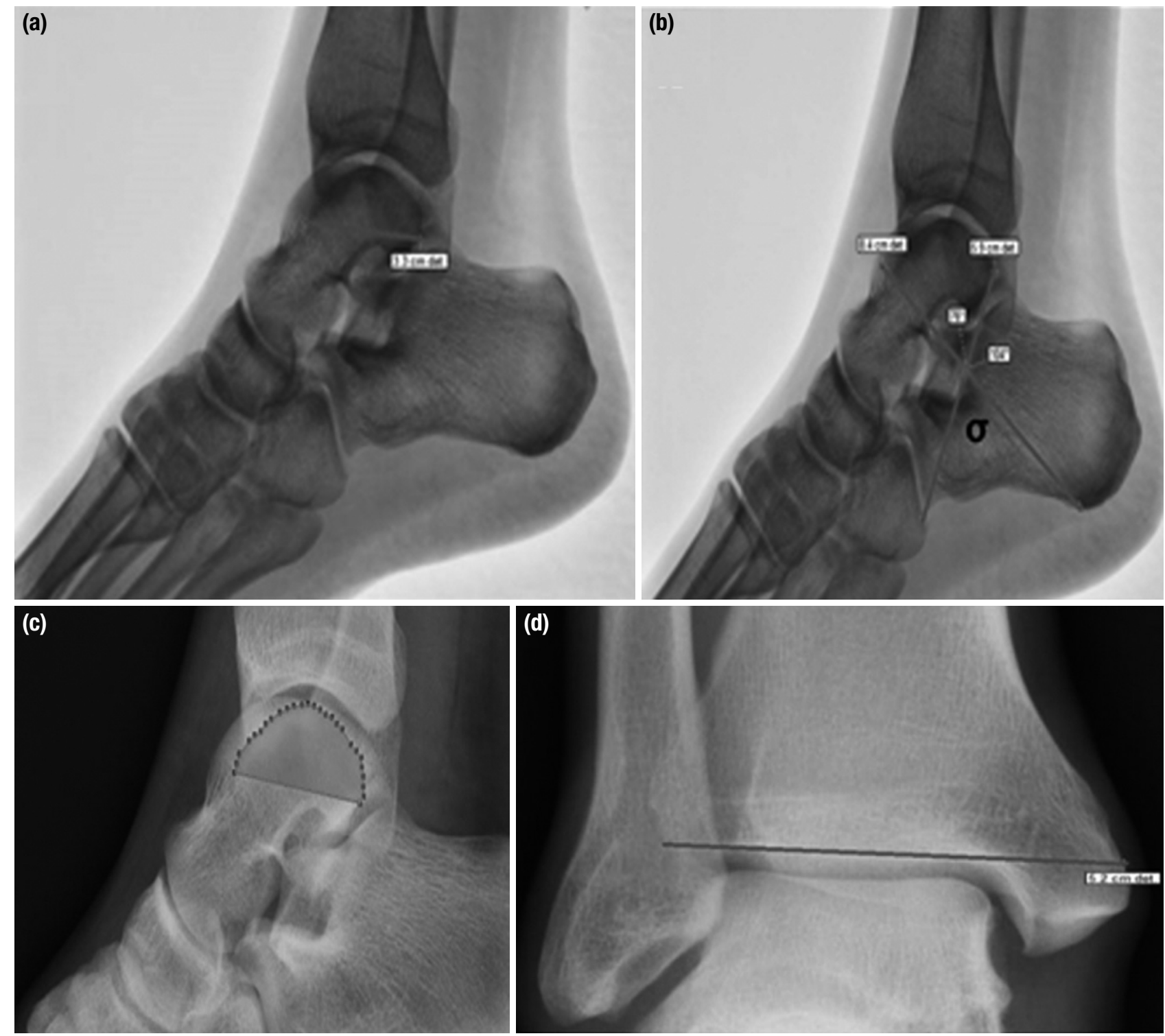

Figure 1. a-d. Talocrural ankle measurement. TSU measurement (a); SIGMA angle (b); TTA measurement (c); TML measurement (d). TSU, measurement of the sagittal length of the trochlea tali; TTA, measurement of the surface area of the trochlea tali; TML, the measurement of the mediolateral diameter of the tibia.

Measurement of the distance between the outermost points of the talocrural joint at the medial and lateral malleoli (ATD): We measured the distance between the outermost points of the talocrural joint by firstly defining the most lateral points of the medial and lateral malleoli and in a way that it passes over the upper border of the talar dome (Fig. 2 c).

Measurement of the angles between lateral malleolus and talus: We measured the angle created from the plane formed from the most lateral upper protruding point of the talus parallel to the lateral side of the tibial cortex on the one hand, and the lowest and upper most medial points of the medial surface of the lateral malleolus (ALFA angle) (Fig. $2 \mathrm{~d}$ ).

Measurement of the angles between medial malleolus and talus: We measured the angle created from the plane formed from the lowermost medial protruding point of the talus parallel to the uppermost medial protruding point of the trochlea tali and the plane formed from the lower most medial protruding point of the talus to the most lateral point of the medial malleolus (DELTA angle). (Fig. 2e) 

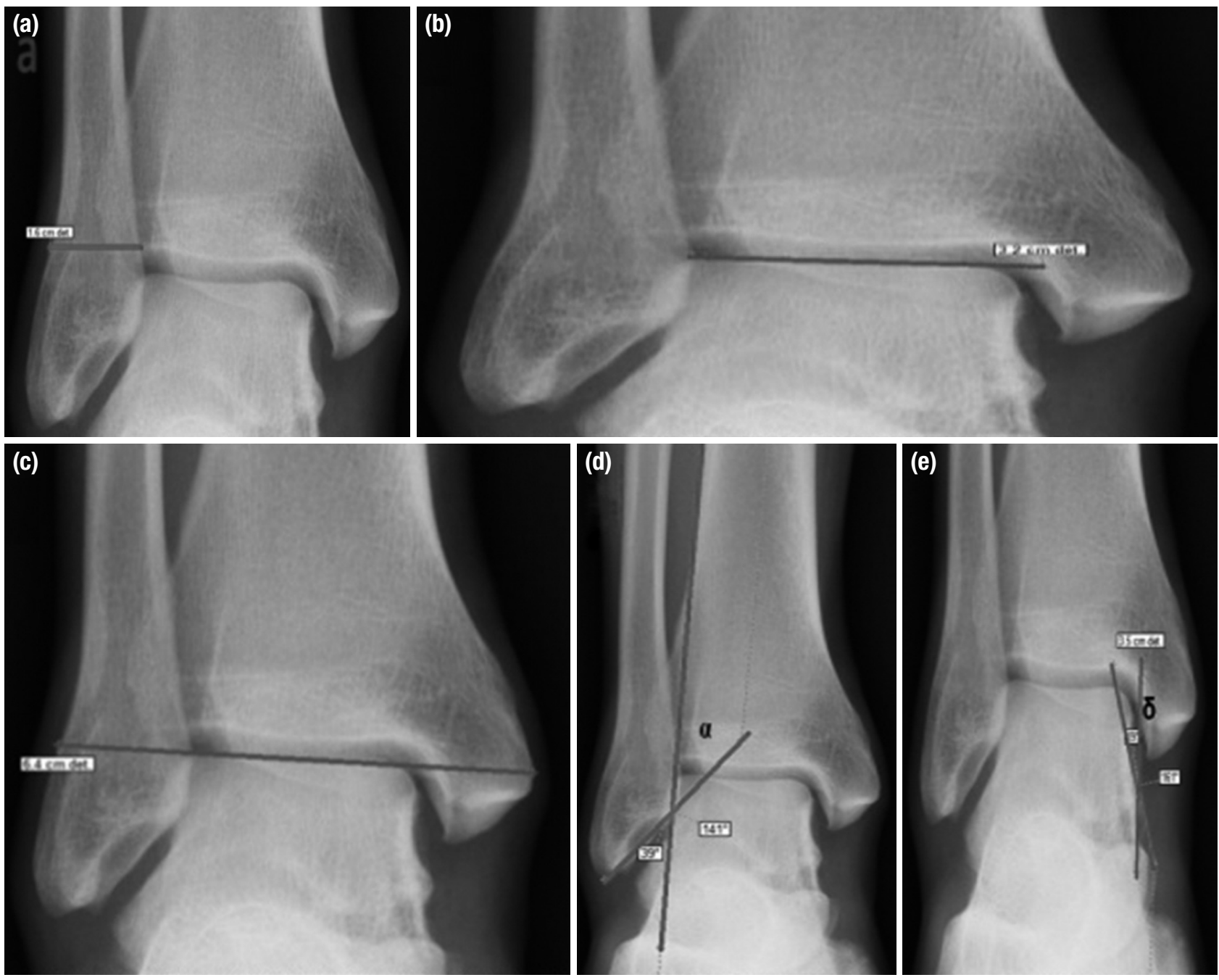

Figure 2. a-e. Talocrural ankle measurement. FML measurement (a); ATI measurement (b); ATD measurement (c); ALFA angle (d); DELTA angle (e). FML, measurement of the mediolateral diameter of the fibula; ATI, measurement of the distance between the innermost points of the talocrural joint at the medial and lateral malleoli; ATD, measurement of the distance between the outermost points of the talocrural joint at the medial and lateral malleoli.

\section{Statistical Analysis}

The IBM SPSS Statistics 23.0 program was used for the statistical evaluations. Two-way ANOVA (variance analysis) was used to evaluate if the morphometric measurements showed differences based on age, sex and both age and sex. All statistical evaluations in which the $\mathrm{p}$ value was calculated as smaller than 0.05 were considered as significant.

All measurements were conducted by two researchers; an anatomist and an expert radiologist. In order to ensure the accuracy of the measurements, accuracy analysis was performed among the measurements held by each researcher and among measurements held by both researchers. To test the accuracy of each of the measurements repeated by each researcher in four weeks' time, the Wilcoxon matched-pairs signed rank test was used. The accuracy between the two researchers was defined by the interclass correlation coefficient (ICC) and the coefficient of variation (CV) $[\mathrm{CV}=$ (standard deviation/mean) $\mathrm{x} \%$ 100]. Values of ICC bigger than 0.75 indicates good accuracy, whereas low CV values show a sensitive error and a necessity for repetition ${ }^{20}$.

\section{Results}

No meaningful difference was seen in the consistency of the measurements held by each researcher. The measurements' consistency of Researcher 1 was found to be 
$93 \%$ and $96 \%$, while for Researcher 2 consistency values were found to be $90 \%$ and $92 \%$. For both researchers, it was determined that all measurements had a high consistency and no significant difference was observed. Regarding the consistency of measurements between both researchers, the interclass correlation coefficient was found as 0.947 and 0.991; as such it was within the reliability level.

The age distribution of males ranged from 10-85 with the mean age found to be 38.8 , while the females' age distribution ranged from 11-79 and the mean age was 40.2. The differences between the mean ages of males and females were found to be not statistically significant (Table 1).

In all of the parameters no difference was observed neither among the age groups $(p>0.347)$ nor among the age groups based on sex $(p>0.453)$. In all of the

Table 1. Distribution of individuals by age and sex

\begin{tabular}{lccc}
\hline Age Groups & $\mathrm{N}$ & $\overline{\mathrm{x}} \pm \mathrm{s}$ & Min-Maks. \\
\hline 1. Group (10-19) & 29 & $16.55 \pm 2.27$ & $10-19$ \\
$\quad$ Male & 15 & $16.467 \pm 2.32$ & $10-19$ \\
Female & 14 & $16.643 \pm 2.30$ & $11-19$ \\
2. Group (20-29) & 44 & $24.77 \pm 3.07$ & $20-29$ \\
$\quad$ Male & 22 & $25.04 \pm 2.86$ & $20-29$ \\
$\quad$ Female & 22 & $24.50 \pm 3.32$ & $20-29$ \\
3. Group (30-39) & 82 & $34.52 \pm 2.61$ & $30-39$ \\
$\quad$ Male & 41 & $34.48 \pm 2.69$ & $30-39$ \\
Female & 41 & $34.561 \pm 2.56$ & $30-39$ \\
4. Group (40-49) & 52 & $43.57 \pm 3$ & $40-49$ \\
Male & 26 & $42.84 \pm 3.05$ & $40-49$ \\
Female & 26 & $44.30 \pm 2.82$ & $40-49$ \\
5. Group (50-59) & 31 & $54.25 \pm 3.09$ & $50-59$ \\
$\quad$ Male & 14 & $54.21 \pm 3.30$ & $50-59$ \\
Female & 17 & $54.29 \pm 3.01$ & $51-59$ \\
6. Group (60-69) & 24 & $64.45 \pm 3.13$ & $60-69$ \\
$\quad$ Male & 11 & $65.27 \pm 3.49$ & $60-69$ \\
Female & 13 & $63.76 \pm 2.74$ & $60-69$ \\
7. Group (70-85) & 13 & $77.08 \pm 4.07$ & $70-85$ \\
Male & 6 & $78.6 \pm 5.07$ & $72-85$ \\
Female & 7 & $76 \pm 3.16$ & $70-79$ \\
Total & 274 & $39.49 \pm 15.85$ & $10-85$ \\
Male & 134 & $38.8 \pm 15.73$ & $10-85$ \\
Female & 140 & $40.2 \pm 15.99$ & $11-79$ \\
\hline
\end{tabular}

age groups the mean of the male measurements was found to be higher compared to the female measurements. In the examination of all the length measurements, it was identified that males in the $5^{\text {th }}$ group and women in the $7^{\text {th }}$ group had the highest values of the TML, TTA and ATU. Furthermore, males and females of the $7^{\text {th }}$ group demonstrated the highest values in the FML and TSU measurements. Only in the ATI measurement, females of the $6^{\text {th }}$ group and males of the $1^{\text {st }}$ group showed the highest values. As regards the angle measurements, $3^{\text {rd }}$ group males and $2^{\text {nd }}$ group females had the highest values in the SIGMA measurements; both $1^{\text {st }}$ group males and females had the highest values in the ALFA measurements; $3^{\text {rd }}$ group males and $5^{\text {th }}$ group females had the highest values in the DELTA measurements (Table 2). According to the correlation analysis, all length parameters were found to be in a positive correlation with each-other. No correlation was found between the length measurements and angular parameters (Table 3 ).

\section{Discussion}

Talocrural joint is one of the joints most frequently injured by sports activities. The traumas of the talocrural joint caused by sports injuries are observed to be at a high level of $15 \%-20 \%$. Injuries are especially seen to occur during running activities and anterior-lateral leaps. The frequency of the talocrural joint traumas observed in football, basketball and volleyball constitutes $25 \%-50 \%$ of all the injuries of the muscle skeleton system $^{4-9}$.

Given that the talocrural joint is relatively more exposed to traumas such as foot twisting, the morphometrical evaluation and the anatomical structure of this joint gain a lot of importance. Besides, the movements of the ankle joint are limited to flexion and extension has a lot of impact on the anatomical structure of the joint ${ }^{10}$.

In many emergency rooms of hospitals, diagnoses are made via direct radiography, ultrasonography and computed tomography (CT) scans, which are more easily accessible ${ }^{11}$. In the diagnosis of some pathologies, direct radiographies are used due to being economical and having a sufficient quality of the image. It is known that in order for the anteromedial tibial and talar osteophytes to be clearly seen in direct radiographies, taking anteromedial oblique graphies will be appropriate. In this way the necessity for expensive imaging methods such as CT and Magnetic 
Table 2. The highest measurement values in the age groups based on sex

\begin{tabular}{|c|c|c|c|c|c|c|}
\hline \multirow[b]{2}{*}{ Measurements } & \multicolumn{3}{|c|}{ Female } & \multicolumn{3}{|c|}{ Male } \\
\hline & & $\% 95$ C.I & Min-Max & & $\% 95$ C.I & Min-Max \\
\hline DELTA & $15.53 \pm 3.34$ & $14.16 \pm 16.9$ & $11-23$ & $15.39 \pm 2.54$ & $14.51 \pm 16.28$ & $11-21$ \\
\hline ALFA & $35.79 \pm 5.54$ & $33.41 \pm 38.16$ & $30-49$ & $34.87 \pm 4.53$ & $32.57 \pm 37.16$ & $30-47$ \\
\hline ATD & $5.81 \pm 0.65$ & $5.51 \pm 6.12$ & $5-7.1$ & $6.66 \pm 0.63$ & $6.1 \pm 7.22$ & $5.8-7.2$ \\
\hline ATI & $2.99 \pm 0.34$ & $2.79 \pm 3.18$ & $2.3-3.7$ & $3.38 \pm 0.28$ & $3.17 \pm 3.6$ & $3-3.8$ \\
\hline TTA & $514.36 \pm 93.03$ & $418.93-609.8$ & $400.02-668.90$ & $669.66 \pm 136.4$ & $602.18-737.14$ & $394.50-880.69$ \\
\hline TSU & $3.77 \pm 0.36$ & $3.46-4.08$ & $3.1-4.1$ & $4.12 \pm 0.31$ & $3.75-4.49$ & $3.8-4.5$ \\
\hline SIGMA & $87.95 \pm 5.38$ & $85.49-90.41$ & 78-101 & $85.49 \pm 5.87$ & $83.68-87.29$ & $72-97$ \\
\hline FML & $1.89 \pm 0.16$ & $1.70-2.06$ & $1.7-2.1$ & $1.92 \pm 0.28$ & $1.70-2.13$ & $1.5-2.2$ \\
\hline TML & $4.81 \pm 0.46$ & $4.39-5.23$ & $4-5.5$ & $5.61 \pm 0.5$ & $5.31-5.90$ & $4.5-6.2$ \\
\hline
\end{tabular}

ATD, measurement of the distance between the outermost points of the talocrural joint at the medial and lateral malleoli; ATI, measurement of the distance between the innermost points of the talocrural joint at the medial and lateral malleoli; TTA, measurement of the surface area of the trochlea tali; TSU, measurement of the sagittal length of the trochlea tali; FML, measurement of the mediolateral diameter of the fibula; TML, the measurement of the mediolateral diameter of the tibia.

Table 3. Relationships among variables

\begin{tabular}{|c|c|c|c|c|c|c|c|c|c|c|c|}
\hline $\mathrm{N}=274$ & TML & FML & SIGMA & TSU & TTA & ATI & ATU & ALFA & BETA & DELTA & GAMA \\
\hline TML & 1 & $0.753^{\star \star}$ & $-0.153^{\star}$ & $0.883^{\star \star}$ & $0.833^{\star \star}$ & $0.804^{\star \star}$ & $0.919^{\star \star}$ & 0.105 & -0.075 & 0.010 & -0.018 \\
\hline FML & $0.753^{\star \star}$ & 1 & -0.091 & $0.700^{\star \star}$ & $0.693^{\star \star}$ & $0.512^{\star \star}$ & $0.731^{\text {** }}$ & 0.088 & -0.089 & -0.020 & 0.016 \\
\hline SIGMA & $-0.153^{\star}$ & -0.091 & 1 & -0.004 & 0.070 & $-0.133^{*}$ & $-0.133^{*}$ & 0.019 & -0.020 & 0.065 & -0.065 \\
\hline TSU & $0.883^{\star \star}$ & $0.700^{\star \star}$ & -0.004 & 1 & $0.853^{\star \star}$ & $0.717^{\star \star}$ & $0.852^{\star \star}$ & 0.077 & -0.045 & 0.020 & -0.025 \\
\hline TTA & $0.833^{\star \star}$ & $0.693^{\star \star}$ & 0.070 & $0.853^{\star \star}$ & 1 & $0.647^{\star \star}$ & $0.793^{\star \star}$ & 0.118 & -0.091 & 0.050 & -0.053 \\
\hline ATI & $0.804^{\star \star}$ & $0.512^{\star \star}$ & $-0.133^{\star}$ & $0.717^{\star \star}$ & $0.647^{\star \star}$ & 1 & $0.858^{\star \star}$ & 0.032 & 0.001 & 0.001 & -0.004 \\
\hline ATU & 0.919 ** & $0.731^{\star \star}$ & $-0.133^{\star}$ & $0.852^{\star \star}$ & $0.793^{\star \star}$ & $0.858^{\star \star}$ & 1 & 0.048 & -0.021 & -0.036 & 0.033 \\
\hline ALFA & 0.105 & 0.088 & 0.019 & 0.077 & 0.118 & 0.032 & 0.048 & 1 & $-1.000^{\star \star}$ & $0.168^{\star \star}$ & $-0.168^{\star \star}$ \\
\hline DELTA & 0.010 & -0.020 & 0.065 & 0.020 & 0.050 & 0.001 & -0.036 & $0.168^{\star \star}$ & $-0.164^{\star \star}$ & 1 & $-1.000^{\star \star}$ \\
\hline
\end{tabular}

TML, the measurement of the mediolateral diameter of the tibia; FML, measurement of the mediolateral diameter of the fibula; TSU, measurement of the sagittal length of the trochlea tali; TTA, measurement of the surface area of the trochlea tali; ATI, measurement of the distance between the innermost points of the talocrural joint at the medial and lateral malleoli.

Resonance Imaging) MRI decreases ${ }^{12,13}$. We chose the direct radiographic imaging in this study in order to be able to examine a high number of individuals, to provide more opportunities to the accessibility of retrospective images, due to the correct results these methods give in the morphometric analysis done in the related region and the low cost.

When evaluating parameters related to the body composition such as body weight, age, height and sex, it is known that body weight and age have quite small impacts on the morphometry of the foot ankle in adult populations ${ }^{14}$. Due to this reason, all morphometric measurements and analyses in this study have been conducted in accordance with the age groups and sex.
Similar to studies of Stagni, Kuo and Kwon ${ }^{15-18}$, in our study we named the parameters as follows: Tibial width (TiW) measurement as ATI length, Malleolar width (MalW) length as ATD length and Trochlea tali length (TaAL) as TSU length. By considering also the racial differences, these values were found to be approximately similar to those of other researchers (Table 4). But, the main difference in our study is that the measurements were performed in much more extensive series.

Fessy et al. ${ }^{19}$ conducted their measurements according to their definition of the medial malleolar angle which follows: the angle created between the straight line formed from the lowest point of the medial malleolus parallel to the lateral cortex of the tibia on the one hand, 
Table 4. The comparison of TiW anterior, MalW and TaAL parameters

\begin{tabular}{|c|c|c|c|c|c|c|c|c|c|c|}
\hline \multirow[b]{2}{*}{ Sex } & \multicolumn{3}{|c|}{$\begin{array}{c}\text { Stagni } \\
\text { Direct Radiography }\end{array}$} & \multirow{2}{*}{$\begin{array}{c}\text { Kuo } \\
\text { Cadaver CT } \\
10 \mathrm{M}-\mathrm{F}\end{array}$} & \multirow{2}{*}{$\frac{\text { Amputated }}{32 \mathrm{M}}$} & $\begin{array}{c}\text { Kuo BT 3D } \\
\text { material CT-3 }\end{array}$ & \multirow{2}{*}{$\frac{\text { Modelling }}{\text { Mean }}$} & \multirow{2}{*}{$\begin{array}{c}\begin{array}{c}\text { Kwon } \\
\text { Retrospektif }\end{array} \\
100 \mathrm{M}-\mathrm{F}\end{array}$} & \multicolumn{2}{|c|}{$\begin{array}{c}\text { Our Study } \\
\text { Retrospektif }\end{array}$} \\
\hline & $23 \mathrm{M}$ & $13 \mathrm{~F}$ & Mean & & & $26 \mathrm{~F}$ & & & $134 \mathrm{M}$ & $140 \mathrm{~F}$ \\
\hline TiW anterior & $33.6 \mathrm{~mm}$ & $28.6 \mathrm{~mm}$ & $31.9 \mathrm{~mm}$ & $31.9 \mathrm{~mm}$ & $34 \mathrm{~mm}$ & $31.7 \mathrm{~mm}$ & $33.3 \mathrm{~mm}$ & $31.1 \mathrm{~mm}$ & $3.2 \pm 0.37 \mathrm{~mm}$ & $2.87 \pm 0.36 \mathrm{~mm}$ \\
\hline MalW & $71 \mathrm{~mm}$ & $63.5 \mathrm{~mm}$ & $69 \mathrm{~mm}$ & $61.5 \mathrm{~mm}$ & $64.0 \mathrm{~mm}$ & $59.9 \mathrm{~mm}$ & $63.1 \mathrm{~mm}$ & $67.7 \mathrm{~mm}$ & $6.59 \pm 0.65 \mathrm{~mm}$ & $5.85 \pm 0.66 \mathrm{~mm}$ \\
\hline TaAL & $43.6 \mathrm{~mm}$ & $37.9 \mathrm{~mm}$ & $41.7 \mathrm{~mm}$ & $32.3 \mathrm{~mm}$ & - & - & - & $35.3 \mathrm{~mm}$ & $3.93 \pm 0.42 \mathrm{~mm}$ & $3.46 \pm 0.42 \mathrm{~mm}$ \\
\hline
\end{tabular}

TiW, Tibial width; MalW, Malleolar width; TaAL, Trochlea tali length.

and the straight line formed from this point parallel to the lateral cortex of the tibia on the other. Meanwhile, in our study the measurement of the angle between the medial malleolus and talus (Delta angle) follows: the angle created between the plane formed from the lower most medial protruding point of the talus to the upper most medial protruding point of the trochlea tali and the plane formed from the lower most medial protruding point of the talus to the most lateral point of the medial malleolus. We believe that our definition of the angle is more accurate than the definition of the Fessy et al. given that their definition of the angle does not include a clear definition of the tibia cortex's border and it can pave the way to unrealistic results in studies.

When comparing the measurements of the lateral malleolar angle, even though the definition is the same in both studies, it is seen that the measurement values of Fessy et al. are smaller (average $\left.14.62^{\circ}\right)^{12}$. The main reason of this difference is thought to be due to the fact that Fessy et al. used mortis graphy, whereas in our study we performed the measurements in the anteroposterior radiographies. In this measurement, given that the anteroposterior radiographies are routinely required from patients, they can be obtained more easily and more practically.

The SIGMA angle we defined is important for revealing the joint deformation and for distinguishing healthy individuals from individuals with pathological joints. Furthermore, we think that it will also serve as a new clinical diagnosis parameter in the literature.

In order to decide on the surgery treatment of the degenerative arthritis that is seen in foot ankle, firstly the symptoms of the patient and the functional necessities need to be understood. For this reason, we believe that the TTA measurement we have added to the literature, will provide for a better follow up of the recovery period during the cure.

Heybeli et al. maintain that it is critical that during the distraction of the talocrural joint the tilt movement of the talus should not exert pressure to the medial and lateral malleoli, in order for the posterior area of the foot ankle to be displayed better ${ }^{21}$. For this reason we believe that a good knowledge on the ALFA and DELTA angles that we described in this study is important.

In our study statistically significant difference between age groups was found in the ATD measurements and no statistically significant difference was found in the ATI angle. While the longitudinal growth of the bones is finalized with the ossification of the epiphyseal line during the development/growth period, the transverse growth of the bones is possible during the whole lifetime ${ }^{22}$. Following this statement, in our study the distance between bone faces in front of each-other during the transverse growth of the bones, does not change statistically, but statistically significant difference was found in the lateral most protruding points of the bones.

\section{Conclusion}

There exist a limited number of studies related to this topic in the literature. We believe that this study will contribute to the literature and will also have an impact on the increase of the success rate for individuals after surgery due to the possibility of the production of the ankle prosthesis in accordance with the individual's sex and it will provide clinicians with easy, new, practical and measurable methods in the cases of degenerative arthritis, osteoarthrosis, subluxation and luxation. 


\section{References}

1. Beynnon BD, Murphy DF, Alosa DM. Predictive factors for lateral ankle sprains: a literature review. Journal of Athletic Training 2002;37(4):376.

2. Hellier CA, Jeffery N. Morphological plasticity in the juvenile talus. Foot and Ankle surgery 2006;12(3):139-47.

3. Prasad N, Prasad M. Morphometric study of medial collateral ligaments of ankle. J Evid Based Med Healthc 2016;3(46):22968.

4. Fong DT-P, Hong Y, Chan L-K, Yung PS-H, Chan K-M. A systematic review on ankle injury and ankle sprain in sports. Sports Medicine 2007;37(1):73-94.

5. Boruta PM, Bishop JO, Braly WG, Tullos HS. Acute lateral ankle ligament injuries: a literature review. Foot \& Ankle International 1990;11(2):107-13.

6. Garrick JG. The frequency of injury, mechanism of injury, and epidemiology of ankle sprains. The American Journal of Sports Medicine 1977;5(6):241-2.

7. Hancı E. Fonksiyonel ayak bileği instabilitesi olan bireylerde ayak bileği evertör ve dorsifleksör kas gruplarına uygulanan eksentrik ve konsentrik kombine izokinetik egzersizin kuvvet ve propriosepsiyon üzerine etkisi [Tıpta uzmanlık tezi]. Bursa: Uludağ Üniversitesi; 2014.

8. Peters JW, Trevino SG, Renstrom PA. Chronic lateral ankle instability. Foot \& Ankle 1991;12(3):182-91.

9. Smith RW, Reischl SF. Treatment of ankle sprains in young athletes. The American Journal of Sports Medicine 1986;14(6):465-71.

10. Tekdemir İ. İnsan ayak bileği ekleminin (art. talocruralis) bağlarının (özellikle lig. deltoideum) statik stabilizatör olarak fonksiyonlarının ve kopma dayanımlarının incelenmesi konusunda araştırmalar [Tipta uzmanlık tezi]. Ankara: Ankara Üniversitesi; 1989.
11. Özdemir ZM, Kerimoğlu Ü. Ekstremitenin travmatik olmayan acilleri. Türk Radyoloji Seminerleri 2016;4:323-39.

12. Tuncer K, Topal M. Erişkin ayak-ayak bileğinin değerlendirilmesi. Derman Tibbi Yayıncılık 2015:560-82.

13. Dobbs MB, Walton T. Autosomal dominant transmission of accessory navicular. The Iowa Orthopaedic Journal 2004;24:84.

14. Blais MM, Green WT, Anderson M. Lengths of the growing foot. J Bone Joint Surg Am 1956;38(5):998-1000.

15. Stagni R, Leardini A, Ensini A, Cappello A. Ankle morphometry evaluated using a new semi-automated technique based on $\mathrm{X}$-ray pictures. Clinical Biomechanics 2005;20(3):307-11.

16. Kuo CC, Lu HL, Leardini A, Lu TW, Kuo MY, Hsu HC. Threedimensional computer graphics-based ankle morphometry with computerized tomography for total ankle replacement design and positioning. Clinical Anatomy 2014;27(4):659-68.

17. Kuo C-C, Lee G-Y, Chang C-M, Hsu H-C, Leardini A, Lu T-W. Ankle morphometry in the Chinese population. Journal of Foot and Ankle Research 2008;1(1): O11.

18. Kwon DG, Sung KH, Chung CY, Park MS, Lee SH, Kim TW, et al. Preliminary findings of morphometric analysis of ankle joint in Korean population. The Journal of Foot and Ankle Surgery 2014;53(1):3-7.

19. Fessy M, Carret J, Bejui J. Morphometry of the talocrural joint. Surgical and Radiologic Anatomy 1997;19(5):299-302.

20. Chang P, Liang K, Lim J, Chung M, Chien L. A comparison of the thresholding strategies of micro-CT for periodontal bone loss: a pilot study. Dentomaxillofacial Radiology 2014.

21. Heybeli N. Burkulmuş Ayak bileğinin değerlendirilmesi. Sted 2002;11(4):129-31.

22. Waschke J, Böckers TM, Paulsen F. Sobotta Anatomi Konu Kitabı Mustafa Fevzi Sargon Elsevier Health Sciences. (Çev) 2015, Germany: Elsevier Health Sciences. 